\title{
Transformation of Self-Directed Learning Abilities Among Distance Learner
}

\author{
Nursyamilah Annuar, Roziana Shaari \\ Management Faculty of Universiti Teknologi Malaysia, 81310 UTM Skudai, Johor Bahru, Malaysia \\ Senior lecturer, Management Faculty of Universiti Teknologi Malaysia, 81310 UTM Skudai, Johor Bahru, \\ Malaysia.
}

\begin{abstract}
The results of increase in knowledge, fast-paced technology and changes in working environment leads adult as learners to be more competitive. As potential human resources, adult learners should cultivate their self-directed learning ability in order to be more competitive. However, adult learners still face great difficulty in gaining new knowledge as today's adult learners are still very much lack of readiness to self-direct in learning. It is important for adult learners who pursue distance learning to possess self-directed learning ability. Therefore, one of the options for these adult learners to develop their self-directed learning ability is through the practice in distance learning. This learning provides a platform for adult learners to planning, implementing and evaluating their own learning activities.
\end{abstract}

\section{Indexing terms/Keywords}

Self-directed learning; distance learning; control of learning; motivation; self-efficacy

\section{Academic Discipline And Sub-Disciplines}

Education; Psychology; Management

\section{SUBJECT CLASSIFICATION}

Adult learning

\section{TYPE (METHOD/APPROACH)}

Literary Analysis

\section{Council for Innovative Research}

Peer Review Research Publishing System

Journal of Social Science Research

\author{
Vol.4, No.1 \\ editor@jssronline.com \\ www.cirworld.com, www.jssronline.com
}


The advancement in the information technology, work life and society leads to changes in an individual's work context as well as affecting the personal growth (Junaidah, 2008). In addressing these changes, distance learners must be able to self-direct not only in their study but also in their work to achieve balance in life. Self-directed learning requires students to improve themselves, work or society. According to Knowles (1975):

In its broadest meaning, "self-directed learning" describes a process in which individuals take the initiative, with or without the help of others to diagnosing their learning needs, formulating learning goals, identifying human and material source for learning, choosing and implementing appropriate learning strategies, and evaluating learning outcomes (p. 18).

Self-directed learning is proven to be an important ability to students in higher education particularly to distance learner as shown in recent studies by many scholars (Raemdonck, Leeden, Segers, \& Thijssen, 2012; Dynan, Cate, \& Rhee, 2008).

There is an issue in self-directed learning ability deficiency (Avdal, 2012; Chou, 2012; Cheng, Kuo, Lin, \& Hseih, 2010) among distance learner students and this may become an obstacle for them to be able to cope in their learning and worse in extreme cases it could affecting their examination results. To overcome these problems, students must have selfefficacy which serves as the best medium to develop self-directed learning ability. In the context of distance learning students focused in this paper, self-efficacy provides a lot of benefits by providing mental and physical preparation during the learning sessions (Yuan, Williams, \& Fang, 2012). Besides, students have the opportunity to learn better as well as to adapt the theoretical learning in university with their working environments or life event. The benefit of self-efficacy for students in their learning sessions are undeniable since numerous studies conducted in various field produced positive outcomes (Gilany \& Abusaad, 2012; Fisher \& King, 2010). Nevertheless, past studies show that self-directed learning can be influenced by motivation (Knight, 2012; Damianoff, 2010) and life satisfaction (Boyer, 2003; Brockett, 1987).

\subsection{LITERATURE REVIEW AND RELATED ISSUES}

Globalization has expanded to the entire world and makes education as one of an economic resource for the country. Effective education will promote and contribute to the country productivity. Therefore, public education has been taken importantly by all developing countries especially United State of America and Europe (Mohd Mahzan, 2009). To produce quality education, every student needs to be able to self-direct their own learning. This can help adult learners received the education which can be used and applied effectively. Self-directed learning can be seen as the contribution of an individual as the whole to the development, responsive to economic change, improve learning outcomes and empower the learning principles to the development of society based on learning (Candy, 1991).

Based on the contribution of self-directed learning to the development of the individual and country (Douglas, 2010), an obstacle to achieve a good performance based on the stages of self-directed learning ability landed as the major issue (Avdal, 2012; Chou, 2012; Cheng, et al., 2010). Knowles (1975) stated that all adult learners are self-directed learners, but their ability to self-direct their own learning are different (Chou, 2012; Li, Tancredi, Daniel, John, \& Daniel 2010). From the overall study that have been carried out on self-directed learning, aspects of student personal characteristics become the important variable in determining a students' ability to self-direct their own learning (Raemdonck et al., 2012; Hall, 2011; Li et al., 2010, Junaidah, 2008; Oladoke, 2006). Most of the past researchers paid less emphasize on factors that influence students to adopt self-directed learning and as the consequence, the effect on the achievement of their study is left fuzzy (Raemdonck, et al., 2012; Robertson, 2011; Du, 2011). However, there is the possibility to develop a student to self-direct their own learning for their own improvement and success in self-directed learning (Raemdonck, et al., 2012; Dynan, Cate, \& Rhee, 2008).

Most of adult learners spent some time to get information and learn new ability (Hiemstra, 1994). Triumph in self-directed learning depends on adult learners attempt to do something (Friedman, 2011; Gibbons, 2002). If the adult learner wants to manage their learning and life, they need to control it in order to make decisions and act well. Students demonstrate internal and external autonomy by learning to seek knowledge, make a commitment, has an interest and motivation (Gibbons, 2002). Students will determine not only what they need to do but also the performance that will be achieved. Self-directed learning requires the confidence, spirit and passion to improve efforts that have been made in learning (Brockett \& Donaghy, 2011; Guglielmino \& Long, 2011). In controlling learning, adult learners will remain responsible for their daily life (Guglielmino \& Long, 2011; Candy, 1991). Students are responsible for learning and using their experience to give their views or ideas, making decisions and choosing the corresponding activity to adapt in their life. In this process, Chou (2012) asserts that further studies are necessary to understand clearly the self-directed learning ability of adult learners. Based on the above issues, the study of an individual's ability to self-direct one's own learning to improve student's achievement still need to be conducted due to the fact that each individual has different personal characteristics (Merriam, 2010), and there has been no concrete studies to explain the self-directed learning of an individual student as a whole (Chou, 2012; Li et al., 2010).

\subsection{Issues on Self-Directed Learning Abilities}


The ability of adult learners to self-direct their learning will involve motivation. Motivation is identified as one of the important concept in the field of education due to the relationship with learning and students' achievement, as well as attracting the interest of investigators (Wlodkowski, 2008). Adult learners who have high level of motivation are able to increase their ability to self-direct their learning (Regan, 2003). However, the low level of students' ability to self-direct their learning requires motivation rather from tutor or lecturer whereby it is actually partly their responsibility (Robertson, 2011; Entwistle, 1998). Motivation is the encouragement that comes from the needs and desires to achieve something. According to Keller (1983), motivation refers to the human tendency to make choices about the experience, goals to be explored and to make choices about the quantity of work needs to be generated to achieve the selection. Motivation can also be said as the success of a plan or stimulus to avoid failure (Regan, 2003). Students who have high levels of motivation mean he has acquired strength to excel in his life (Muhammad Shatar, 2005; Regan, 2003). Motivation is something that exist (or none) in self and mind that will determine success or failure in any undertaken effort.

The discussion of motivation theory developed from behaviourist approach to cognitivist approach will looks at the theory components from three aspects namely value, expectancy and affective (Lynch, 2006; Duncan \& McKeachie, 2005; Williams, Burden, \& Lanvers, 2002; Pintrich, Smith, Garcia \& McKeachie, 1991). Value factor is seen as the reason of students to engage in learning that involves three aspects namely intrinsic motivation, extrinsic motivation and task or course value. Expectancy factor is looking at the students' level of trust and perceptions towards their ability to achieve learning goals that have been set. Affective factor on the other hand looks at the state of unpleasant feelings and emotions that affect the students' psychology and behaviour. Nevertheless, most of the studies that have been carried out only focus on students' internal motivation without thoroughly reviewing the external motivation that also able to increase the ability of students to self-direct their learning (Knight, 2012; Damianoff, 2010). This study will take about two value factors namely intrinsic, extrinsic and expectancy factor.

Research on intrinsic motivation demonstrated that the intrinsic motivation is not a major issue in self-directed learning but extrinsic motivation also has its effect towards students' self-directed learning (Robertson, 2011). For example, a promotion given by the organization is one of the extrinsic motivation that helps to improve students' ability to self-direct their learning (Bostwick, 2010). Moreover, Noor Fitriyati (2009) stated that motivation factors in self-directed learning field examined in the past literature are still not enough to explain the intrinsic and extrinsic motivation factors. Kim and Park (2011) believed that motivation factors cover major effect on learning, thus descriptive on only some particular exclusive factors are insufficient. The above issues provide clear justification that further studies are necessary on the relationship between motivation and students' ability towards self-directed learning.

Factors of interest in learning, curiosity, love studying in university and like the subjects offered encourage students to think critically and enhance their self-directed learning. R. Dunn and K. Dunn (1978) stated that intrinsic motivation built when there is internal encouragement in students to participate in the self-directed learning. Studies conducted by Ghazali, Nik and Parilah (2010) on the students at Universiti Teknologi Mara shows that intrinsic motivation has significant positive relationship with learning performance.Based on the above explanation, one hypothesis can be developed. Hence, the hypothesis that can be developed here is there is a positive significant effect of motivation on self-directed learning.

Most of adult learners are not ready to control their learning as a whole and requires a learning experience with the help of teachers (Raidal \& Volet, 2009; Howland \& Moore, 2002). Bandura (1997) stated that self-efficacy is the perceived ability of the individual to cope with specific situations in relation to the self-assessment of their ability to perform any act that has to do with the specific task or situation. Dynan, Cate and Rhee (2008) found that students who are consistent in their selfefficacy and possess necessary structure of learning will gain enough strength to improve learning achievement. At present, study on self-efficacy is still complex thus it requires a more in-depth study (Merriam, 2010) because it is important to identify learning needs of the students (Yuan, Williams, \& Fang, 2012). Students who are lack of self-efficacy will face more trembling or rumbling moments when the project or case study are assigned to them as individual tasks (Yuan, Williams, \& Fang, 2012). However, the student who has a high self-efficacy is more successful in learning compared to students with low self-efficacy towards self-directed learning (Gilany \& Abusaad, 2012; Fisher \& King, 2010). For each student, the self-efficacy is important to ensure students can receive and apply the knowledge learned with ease. Past studies had given less emphasis on self-efficacy factors which mediates the relationship between motivation and life satisfaction with self-directed learning. Precisely, more in-depth study on self-efficacy should be given more attention because of its importance (Gilany \& Abusaad, 2012; Mead, 2011).

Bandura (1997) defines self-efficacy as the belief earned in one's capabilities to organize and perform a task or action to achieve goals. Appelbaum and Hare (1996) stated that self-efficacy helps improve the performance of students in their self-directed learning. Most of the previous studies used self-efficacy to examine issues related to psychology. For example, McAuley, Lox and Duncan (1993) concluded that self-efficacy is a factor to mediate between motivation and efficiency of students in their learning. Furthermore, Hastings and Brown (2002) revealed that self-efficacy helped in resolving the relationship between anxiety and depression faced by students in their learning. Several previous studies had shown that self-efficacy acts as a mediator to improve students' behaviour with academic achievement (Seo, 2008).

Previous research conducted also found that self-efficacy are correlated or could be applied as pointers to clinical problems like fright, depression, assertiveness to stress in different kinds of contexts, to control pain, health and also for performance (Damianoff, 2010; Lent \& Brown, 2006). Saiamak and Pole (2010) study showed self-efficacy and anxiety 
have a negative correlation coefficient among students and life satisfaction. Masitah, Azizi, Ahmad, Bahaman, Ramli, Noriati and Mohamed (2011) stated that self-efficacy has a significant relationship between academic achievements of students with their health. Self-efficacy is also a mediator to make career choices and achieve career satisfaction (Lent \& Brown, 2006; Lent, Brown \& Hackett, 1994). In addition, self-efficacy is often associated with self-confidence (Selk, 2009). Based on the above explanation, two hypotheses can be developed. Therefore, the hypothesis can be developed here are; 1) There is a mediate effect of self-efficacy which is significant and positive between motivation with self-directed learning, and 2) There is a mediate effect of self-efficacy which is a significant and positive between life satisfaction and self-directed learning.

\subsection{Issues on Distance Learning}

Distance learners are found low on personal aspiration and study habits and they are also less motivated because of their socio-economic situations and have little attitude towards their study centres (Singh et al., 2012). Regular classroom teaching facilitates regular interaction between students and teacher that helps students to solve their problems timely (Singh et al., 2012). Some authors discuss the relationship between education environment, students' self-efficacy and self-directed learning ability among medical students (Hamlett, 2006; Roberts, 2009), however, little literature explores distance students' readiness for self-directed learning (Yuan et al., 2012).

Nevertheless, development self-directed learning ability require a non-specific time limit and sometime dependable on the individual as well as other external factors such as thing required exposure to various experiences. Therefore, distance learner should be aware and have the initiatives to prepare themselves by actively participated in class and distance learning program throughout the duration of their studies (Abdullah et al., 2008; Hamlett, 2006; Roberts, 2009).

\subsection{DISCUSSION FOR FUTURE RESEARCH}

Most of the researchers have suggested that the self-direction in learning is important (Merriam, 2010; Brockett \& Hiemstra, 1991), very little research has been conducted thoroughly in focusing on readiness of students to date. Most researches have relied on measuring self-directed learning in institutional learning (Avdal, 2012; Cheng et al., 2010). For further research, more empirical research focused on motivation, control in learning and self-efficacy is needed.

Researchers and practitioners need more empirical evidences in terms of model for adult learners to be able to self-direct their learning effectively and their effect on the adult learners' learning life. Besides, only a few studies have been conducted in an international setting. More studies are needed from around the world to help identify commonalities and differences across culture.

\subsection{CONCLUSION}

Based on the literature, it is expected that a certain degree of self-directed learning ability will be achieved during the distance learning programme. When the study is implemented, the findings will contribute to the stakeholders (distance learner students, universities and higher education institution) and the body of knowledge. Stakeholders can identify the loop holes where they can improve self-directed learning ability with better planning and implementation. Consequently, distance learner students understand the objective of the learning is not only to integrate theory and practice in real world but also for their self-directed learning ability development.

\section{ACKNOWLEDGMENTS}

We would like to thank School of Graduate Studies (SPS) UTM and Research Management Centre (RMC) UTM for assisting this study financially through UTM Zamalah Scholarship.

\section{REFERENCES}

Abdullah, M. M., Koren, S. F., Muniapan, B., \& Rathakrishnan, B. (2008). Adult Participation in Self-Directed Learning Programs. International Education Studies, 1(3), 66-72.

Appelbaum, S. H., \& Hare, A. (1996). Self-efficacy as a mediator of goal setting and performance: some human resource application. Journal of Managerial Psychology, 11, 33 - 47.

Avdal, E. U. (2012). The effect of self-directed learning abilities of student nurses on success in turkey. Nurse Education Today, 197, 350-356. 
Bandura, A. (1997). Self-efficacy: the exercise of control. New York:Freeman.

Bostwick, D. T. (2010). the relationship between background demographics and motivational orientation for learning of adult education students and their career choices. Doctoral dissertation, TUI University.

Boyer, N. R. (2003). The learning contract process: scaffolds for building social, self-directed learning. Quarterly Review of Distance Education, 4, 369-383.

Brockett, R. G., \& Donaghy, R. C. (2011). Self-directed learning: the Houle connection. International Journal of SelfDirected Learning, 8, 1-10.

Brockett, R. G., \& Hiemstra, R. (1991). Self-direction in adult learning: perspectives on theory, research, and practice. London and New York: Routledge.

Brockett. R. G. (1987). Life satisfaction and learner self-direction: enhancing the quality of life during later years. Educational Gerontology, 13, 225-237.

Cheng, S. F., Kuo, C. L., Lin K. C. \& Hseih J. L. (2010). Development and preliminary testing of a self-rating instrument to measure self-directed learning ability of nursing students. International Journal of Nursing Studies, 47, 1152-1158.

Chou, P. N. (2012). Effect of students' self-directed learning abilities on online learning outcomes: two exploratory experiments in electronic engineering. International Journal of Humanities and Social Science, 2, 172-179.

Damianoff, D. (2010) Self-directed learning, lifelong learning and transformative learning in the society for creative anachronism. Doctoral dissertation, Brock University.

Douglas, E. (2010). A study of barriers to adult self-directed learning. Doctoral dissertation, University of Pheonix.

Duncan, T. G., \& McKeachie, W. J. (2005). The making of the motivated strategies for learning questionnaire. Educational Psychologist, 40, 117-128.

Dunn, R., \& Dunn, K. (1978). Teaching students through their individual learning styles. Reston: Reston Publishing.

Dynan, L., Cate, T. \& Rhee, K. (2008). The impact of leaming structure on students' readiness for self-directed learning. Journal of Education for Business, 84, 96-100.

Entwistle, N. (1998). Motivation and approaches to learning: motivating and conceptions of teaching. London: Kogan Page Association.

Fisher, M. \& King, J. (2010). The self-directed learning readiness scale for nursing education revisited: a confirmatory factor analysis. Nurse Education Today, 30, 44-48.

Friedman, D. (2011). The thought exchange: overcoming our resistance to living a sensational life. New York: Library Tales Publishing.

Ghazali Yusri, Nik Mohd Rahimi \& Parilah M. Shah (2010). Kebimbangan ujian dan motivasi dalam kalangan pelajar kursus bahasa arab dalam konteks kemahiran lisan. Asean Journal of Teaching and Learning in Higher Education, 2, 5063.

Gibbons, M. (2002). The self-directed learning handbook: challenging adolescent students to excel. San Francisco: Jossey-Bass.

Gilany, A. H., \& Abusaad FES. (2012). Self-directed learning readiness and learning styles among saudi undergraduate nursing students. Nurse Education Today, 1 (1) 1-5.

Guglielmino L. M. \& Long H. B. (2011). The international self-directed learning symposium: a 25-year perspective. International Journal of Self-Directed Learning, 8 (1), 1-7.

Hall, J.D. (2011). Self-directed learning characteristics of first-generation, first-year college students participating in a summer bridge program. Doctoral dissertation, University Of South Florida.

Hamlett, C. (2006). Self-Directed Learning and Achievement in A Blackboard-based College Algebra Course. PhD Thesis. Walden University.

Hastings, R. P., \& Brown, T. (2002). Behaviour problems of children with autism, parental self-efficacy, and mental health. American Journal on Mental Retardation, 107, 222-232. 
Hiemstra, R. (1994). Overcoming resistance to self-direction in adult learning. San Francisco: Jossey-Bass.

Howland, J. L., \& Moore, J. L. (2002). Students' perceptions as distance learners in internet-based courses. Distance Education, 23, 183-195.

Junaidah Hashim (2008). Competencies acquisition through self-directed learning among Malaysian managers. Journal of Workplace Learning, 20, 259-271.

Keller, J. M. (1983). Motivational design of instruction. In C.M. Reigeluth (Ed.). Instructional design theories and models: an overview of their current status. Hillsdale: Erlbaum.

Kim, M. \& Park, S. Y. (2011). Factors affecting the self-directed learning of students at clinical practice course for advanced practice nurse. Asian Nursing Research, 5, 48-59.

Knight, S. G. (2012). An examination of self-directed learning readiness in executive-level fire officers. Doctoral dissertation, University of South Florida.

Knowles, M. S. (1975). Self-directed learning: a guide for learners and teachers. New York: Association Press.

Lent, R. W., \& Brown, S. D. (2006). Integrating person and situation perspectives on work satisfaction: a social-cognitive view. Journal of Vocational Behavior, 69, 236-247.

Lent, R. W., Brown, S. D., \& Hackett, G. (1994). Toward a unifying social cognitive theory of career and academic interest, choice, and performance. Journal of Vocational Behavior, 45, 79-122.

Li, S. T., Tancredi, Daniel J. C., John, P. T., \& Daniel, C. (2010). Factors associated with successful self-directed learning using individualized learning plans during pediatric residency. Academic paediatrics, 10, 124-130.

Lynch, D. J. (2006). Motivational factors, learning strategies and resource management as predictors of course grades. College Student Journal, 40, 423-428.

Masitah Mohd. Yusof, Azizi Muda, Ahmad Makmom, Bahaman Abu Samah, Ramli Basri, Noriati A. Rashid \& Mohamed Khaidir Alias (2011). Faktor-faktor yang mempengaruhi efikasi-kendiri guru sekolah menengah di malaysia dalam pelaksanaan pendidikan alam sekitar. Malaysian Journal of Environmental Management, 12, 91-111.

McAuley, E., Lox, C., \& Duncan, T. E. (1993). Long-term maintenance of exercise, self-efficacy and physiological change in older adults. Journal of Gerontology, 48, 218-224.

Mead, M.S. (2011). The effect of self-directed learning readiness and online course quality ratings on student satisfaction and academic performance in undergraduate e-learning. Doctoral dissertation, University Of Missouri-Kansas City.

Merriam, S. B. (2010). Adult education-adult learning, instruction and program planning. Adult Education, 6, 12-17.

Mohd Mahzan Awang. (2009, 16 Disember). Cara finland martabatkan guru. Utusan Malaysia. p7.

Muhammad Shatar Sabran (2005). 7 Rahsia kecemerlangan akademik. Kuala Lumpur: Utusan Publications and Distributors.

Noor Fitriyati Binti Abdul Samad (2009). Hubungan motivasi dan pembelajaran kendiri (self-directed learning): satu kajian di kementerian pelajaran malaysia. Master thesis, Universiti Utara Malaysia.

Oladoke, A. O. (2006). Measurement of self-directed learning in online learners. Doctoral dissertation, Capella University.

Pintrich, P. R., Smith, D. A. F., Garcia, T., \& McKeachie, W. J. (1991). A Manual for the use of the motivated strategies for learning questionnaire (MSLQ). Michigan:University of Michigan Publication.

Raemdonck, I., Leeden, M. V., Segers, M., \& Thijssen, J. (2012).Understanding work-related learning: the case of ICT workers. Journal of Workplace Learning, 24, 416-429.

Raidal, S. L., \& Volet, S. E. (2009). Preclinical students' predispositions towards social forms of instruction and selfdirected learning: a challenge for the development of autonomous and collaborative learners. Springer, 57, 577-596.

Regan, J. A. (2003). Motivating students towards self-directed learning. Nurse Education Today, 23, 593-599.

Roberts, J. M. (2009). A mixed methods study of secondary distance-learning students: Exploring Learning Styles. PhD Thesis. 
Robertson, J. (2011). The educational affordances of blogs for self-directed learning. Computers and Education, 57, 16281644.

Selk, J. (2009). Ten minutes toughness: the mental training program for winning before the game begins. San Francisco: Mc. Graw Hill.

Seo, E. H. (2008) Self-efficacy as a mediator in the relationship between self-oriented perfectionism and academic procrastination. Social Behaviour and Personality, 36, 753-64.

Singh, S., Singh, A., Singh, K., \& Sharma, A. (2012). in Open versus Traditional Education in India, 10(1), 45-51.

Williams, M., Burden, R. \& Lanvers, U. (2002). 'French is the language of love and stuff': student perceptions of issues related to motivation in learning a foreign language. British Educational Research Journal, 28, 503-525.

Wlodkowski, R. J. (2008). Enhancing adult motivation to learn: a comprehensive guide for teaching all adults. San Francisco: Jossey-Bass Incorporation Publishers.

Yuan, H. B., Williams, B., \& Fang, J. B. (2012). Chinese baccalaureate nursing students' readiness for self-directed learning. Nurse Education Today, 32, 427-431.

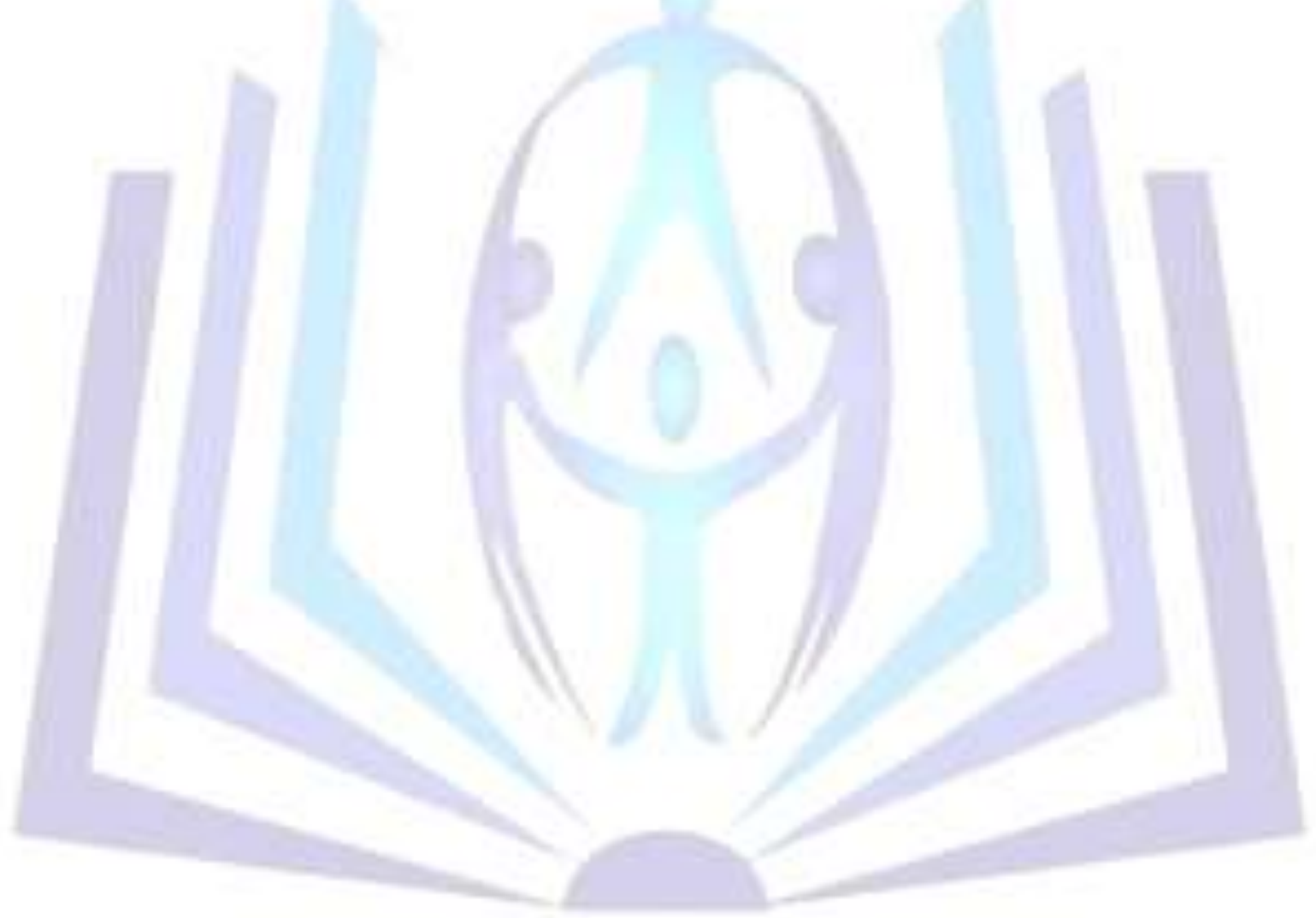

